\title{
Synthesis, Crystal Identification, and Thermal Studies of a New Organic-Inorganic Hybrid Yttrium (III) Complex with Squarate
}

\author{
LOUIZA ZENKHRI and AHMED BOUTARFAIA \\ 'Univ- Ouargla, Chemistry Department, Faculty of Mathematics and Matter Sciences \\ BP 511 Route Ghardaia, Ouargla, -30 000, Algeria. \\ ${ }^{*}$ Corresponding author E-mail: louizazenkhri@yahoo.fr \\ http://dx.doi.org/10.13005/ojc/330345
}

(Received: April 22, 2017; Accepted: May 19, 2017)

\begin{abstract}
During studies of possible synthesis routes to inking amines into crystal lattice of metals squarate complexes, the reaction of the squarate anions, amine and yttrium under acid conditions have led to an isotype of $\mathrm{Eu}\left(\mathrm{H}_{2} \mathrm{O}\right)_{6}\left(\mathrm{C}_{4} \mathrm{O}_{4}\right)\left(\mathrm{HC}_{4} \mathrm{O}_{4}\right) \cdot \mathrm{H}_{2} \mathrm{O}$. The synthesis and identification of the new complex with yttrium (III) is described. The crystal structure with Europium is already reported. This compound was identified by powder X-ray diffraction and its crystal structure properties are determined.
\end{abstract}

Keywords: Squarate, Hybrid Material, RDX Identification, Diffractogram Indexing.

\section{INTRODUCTION}

Metals-carboxylate family are one of the most important materials attracting researchers in the last decade ${ }^{1,2,3,4,5}$ owing to their interesting molecular topologies ${ }^{6}$. They present a great interest follows their hybrid character and three-dimensional networks ${ }^{7,8,9}$. Recently, a large number of studies have been carried out on metal squarates with an open structure. The squarate dianion $\left(\mathrm{C}_{4} \mathrm{O}_{4}{ }^{2-}\right)$ can link metal ions in various coordination modes through the oxygen atoms ${ }^{10}$.

In our own investigations, we are interested in the synthesis and characterization of complexes of yttrium squarate with templates such as ethylenediamine $(\mathrm{Ed})^{11}$, piperazine (pip), 1,4diazabicyclo [ 2.2.2] octane (Dabco). The inking of the amines in the crystal lattices participates in the enlargement of the pores or the tunnels formed by the frameworks of these materials.

In the present study, we describe the synthesis, and spectroscopy, XDR identification and thermal behaviour of the new isotype.

\section{MATERIALS AND METHODS}

All chemicals used were analytical reagents and purchased commercially. Diffraction powder 
experiments were performed at room temperature on a D8 Advence X-ray spectrometer. The sample for measurement was prepared by depositing the dried powder on a silicon sample holder. The structures were identified using DIFFRAC EVA V3.1 program $^{12}$. The crystal lattice search was carried out with the Dicvol 06 program $^{13}$. The program used for powder pattern simulation and molecular charts is a mercury program $^{14}$. The crystallographic data file used number is 1194867. Thermogravimetry analyses were carried out on a STA 449 F3 Jupiter. Thermal decomposition was recorded for $32 \mathrm{mg}$ samples in $\left(\mathrm{N}_{2}\right)$ flow with a heating rate of $5^{\circ} \mathrm{min}^{-1}$ up to $550{ }^{\circ} \mathrm{C}$.

\section{Synthesis Of $\mathrm{Y}\left(\mathrm{H}_{2} \mathrm{O}\right)_{6}\left(\mathrm{C}_{4} \mathrm{O}_{4}\right)\left(\mathrm{Hc}_{4} \mathrm{O}_{4}\right) \cdot \mathrm{H}_{2} \mathrm{O}$}

A solution of yttrium nitrate hexahydrate $(0.19 \mathrm{~g})$ in water $(5 \mathrm{ml})$ was added drop wise to a solution of (Ed) $0.4 \mathrm{ml}$ or (Pip) $0.48 \mathrm{~g}$ or (Dabco) 0.22 $\mathrm{g}$ in distilled water $(10 \mathrm{ml})$. The solutions immediately became turbid and were homogenized by the addition of a drop of $\mathrm{HNO}_{3}$ with stirring for 5 minutes at $40^{\circ} \mathrm{C}$. Then, $0.1 \mathrm{~g}$ of squaric acid in $(10 \mathrm{ml})$ water was added drop wise. The clear solutions formed were stirred for $4 \mathrm{~h}$ at room temperature, and then colorless crystals formed were filtered and washed with water and dried in air.

\section{RESULTS AND DISCUSSION}

\section{X-Ray diffraction (XRD)}

The XRD experimental data of the synthesized product agree with simulated diffracto gram with mercury 3.8 software for $\mathrm{Eu}\left(\mathrm{H}_{2} \mathrm{O}\right)_{6}\left(\mathrm{C}_{4} \mathrm{O}_{4}\right)$ $\left(\mathrm{HC}_{4} \mathrm{O}_{4}\right) \cdot \mathrm{H}_{2} \mathrm{O}^{15}$ complex with a shift involving the difference between the ionic rays between europium and Yttrium. FIG 1

\section{Diffractogram indexing of $\mathrm{Y}\left(\mathrm{H}_{2} \mathrm{O}\right)_{6}\left(\mathrm{C}_{4} \mathrm{O}_{4}\right)\left(\mathrm{HC}_{4} \mathrm{O}_{4}\right)$. $\mathrm{H}_{2} \mathrm{O}$}

Indexing with DIVCOL 06 program leads in a monoclinic unit cell with parameters noted in Table 1 and figures of merit $M$ $(24)=40.4, F(24)=89.5(0.0037,73)$ revealing crystallization quality. The elemental cell in compound described by Jean-Francois Petit, and al is voluminous that we report. This justifies the shift noted in the diffractograms of Fig. 2.

\section{Thermal analyses of $\mathrm{Y}\left(\mathrm{H}_{2} \mathrm{O}\right)_{6}\left(\mathrm{C}_{4} \mathrm{O}_{4}\right)\left(\mathrm{HC}_{4} \mathrm{O}_{4}\right) \cdot \mathrm{H}_{2} \mathrm{O}$}

The thermal behaviours of $\mathrm{Y}\left(\mathrm{H}_{2} \mathrm{O}\right)_{6}\left(\mathrm{C}_{4} \mathrm{O}_{4}\right)$ $\left(\mathrm{HC}_{4} \mathrm{O}_{4}\right) \cdot \mathrm{H}_{2} \mathrm{O}$ show a three stage mass loss (FIG.3). The first stage between 90 and 113 correspond to elimination of the own water molecule, with a mass

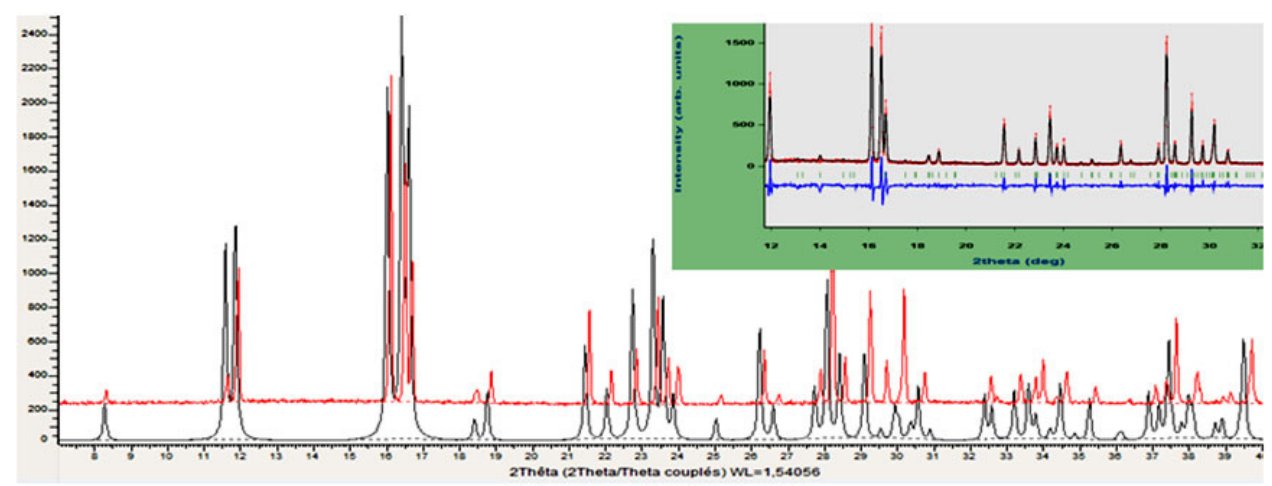

Fig. 1:Parts of the experimental powder diffraction pattern of $\mathrm{Y}\left(\mathrm{H}_{2} \mathrm{O}\right)_{6}\left(\mathrm{C}_{4} \mathrm{O}_{4}\right)\left(\mathrm{HC}_{4} \mathrm{O}_{4}\right) \cdot \mathrm{H}_{2} \mathrm{O}$ (red) and the powder pattern calculated from the atomic coordinates of the europium related compound black with part of Rietveld plot.

Table1 :Cell parameters of $\mathrm{M}\left(\mathrm{H}_{2} \mathrm{O}\right)_{6}\left(\mathrm{C}_{4} \mathrm{O}_{4}\right)\left(\mathrm{HC}_{4} \mathrm{O}_{4}\right) \cdot \mathrm{H}_{2} \mathrm{O} \mathrm{M}=\mathrm{Eu}$, $\mathrm{Y}$.

\begin{tabular}{lccccccc}
\hline & $\mathbf{a}(\AA)$ & $\mathbf{b}(\AA)$ & $\mathbf{c}(\AA)$ & $\alpha\left(^{\circ}\right)$ & $\beta\left(^{\circ}\right)$ & $\gamma\left(\left(^{\circ}\right)\right.$ & $\mathbf{V}\left(\AA^{3}\right)$ \\
\hline $\begin{array}{l}\mathrm{Eu}(\mathrm{H} 2 \mathrm{O}) 6(\mathrm{C} 4 \mathrm{O} 4) \\
(\mathrm{HC4O} 4) . \mathrm{H} 2 \mathrm{O}\end{array}$ & $15.263(2)$ & $14.898(\mathrm{l})$ & $6.354(\mathrm{l})$ & 90 & $92.24(1)$ & 90 & 1444 \\
$\begin{array}{l}\mathrm{Y}(\mathrm{H} 2 \mathrm{O}) 6(\mathrm{C} 4 \mathrm{O} 4) \\
(\mathrm{HC4O4}) . \mathrm{H} 2 \mathrm{O}\end{array}$ & 15.198 & 14.909 & 6.3209 & 90 & 92.271 & 90 & 1421.60 \\
\hline
\end{tabular}


loss of 9.13,whereas in the second step the six water molecules coordinated to the metal atoms are emitted 115 and 260 with a mass loss of 19.33 . In the last stage, decomposition of both squarate and mono hydrogen squarate ligands. The thermal decomposition product was identified as $\mathrm{Y}_{2} \mathrm{O}_{3}$. The final decomposition products of the complex was identified by powder RDX with the corresponding diffractogram obtained for the pure oxide.

Our work aim lies in hybrid materials preparation, intercalating amines in their crystal lattices. In our approach, several procedures were tested. The only resulting complex is

Table 2 :Indexing data of x-ray diffraction pattern for $\left.\mathrm{Y}_{(} \mathrm{H}_{2} \mathrm{O}\right)_{6}\left(\mathrm{C}_{4} \mathrm{O}_{4}\right)\left(\mathrm{HC}_{4} \mathrm{O}_{4}\right) \cdot \mathrm{H}_{2} \mathrm{O}$

\begin{tabular}{|c|c|c|c|c|c|c|c|c|}
\hline H & K & $\mathbf{L}$ & DOBS & DCAL & DOBS-DCAL & 2TH.OBS & 2TH.CAL & DIF.2TH \\
\hline 1 & 1 & 0 & 10.65770 & 10.65615 & 0.00155 & 8.289 & 8.291 & -0.001 \\
\hline 2 & 0 & 0 & 7.62048 & 7.62068 & -0.00020 & 11.603 & 11.603 & 0.000 \\
\hline 0 & 2 & 0 & 7.42754 & 7.43064 & -0.00310 & 11.906 & 11.901 & 0.005 \\
\hline 1 & 1 & -1 & 5.50770 & 5.50758 & 0.00012 & 16.079 & 16.080 & 0.000 \\
\hline 1 & 1 & 1 & 5.37547 & 5.37484 & 0.00062 & 16.478 & 16.480 & -0.002 \\
\hline 2 & 2 & 0 & 5.31544 & 5.31458 & 0.00086 & 16.665 & 16.668 & -0.003 \\
\hline 0 & 2 & 1 & 4.80958 & 4.81614 & -0.00657 & 18.432 & 18.407 & 0.025 \\
\hline 3 & 1 & 0 & & 4.80089 & 0.00868 & & 18.466 & -0.034 \\
\hline 1 & 3 & 0 & 4.70681 & 4.70500 & 0.00181 & 18.838 & 18.846 & -0.007 \\
\hline 2 & 1 & -1 & & 4.70778 & -0.00097 & & 18.834 & 0.004 \\
\hline 2 & 2 & -1 & 4.12524 & 4.12493 & 0.00031 & 21.524 & 21.525 & -0.002 \\
\hline 2 & 2 & 1 & 4.01385 & 4.01382 & 0.00004 & 22.129 & 22.129 & 0.000 \\
\hline 0 & 3 & 1 & 3.89364 & 3.89645 & -0.00280 & 22.821 & 22.804 & 0.017 \\
\hline 3 & 1 & -1 & & 3.89448 & -0.00083 & & 22.816 & 0.005 \\
\hline 1 & 3 & -1 & 3.79762 & 3.79678 & 0.00084 & 23.406 & 23.411 & -0.005 \\
\hline 4 & 0 & 0 & & 3.80339 & -0.00578 & & 23.370 & 0.036 \\
\hline 1 & 3 & 1 & 3.75339 & 3.75242 & 0.00096 & 23.686 & 23.692 & -0.006 \\
\hline 3 & 1 & 1 & & 3.75606 & -0.00268 & & 23.669 & 0.017 \\
\hline 0 & 4 & 0 & 3.70846 & 3.70871 & -0.00025 & 23.977 & 23.975 & 0.002 \\
\hline 3 & 2 & -1 & 3.53982 & 3.54465 & -0.00483 & 25.137 & 25.103 & 0.035 \\
\hline 3 & 3 & 0 & & 3.54003 & -0.00021 & & 25.136 & 0.001 \\
\hline 4 & 2 & 0 & 3.38341 & 3.38375 & -0.00034 & 26.320 & 26.317 & 0.003 \\
\hline 2 & 4 & 0 & 3.33335 & 3.33297 & 0.00038 & 26.722 & 26.725 & -0.003 \\
\hline 0 & 4 & 1 & 3.19961 & 3.19872 & 0.00089 & 27.861 & 27.869 & -0.008 \\
\hline 4 & 0 & 1 & & 3.20324 & -0.00363 & & 27.829 & 0.032 \\
\hline 0 & 0 & 2 & 3.16232 & 3.16255 & -0.00023 & 28.197 & 28.195 & 0.002 \\
\hline 1 & 0 & -2 & 3.12532 & 3.12100 & 0.00432 & 28.538 & 28.578 & -0.040 \\
\hline 3 & 3 & -1 & & 3.12570 & -0.00038 & & 28.534 & 0.004 \\
\hline 1 & 1 & -2 & 3.05349 & 3.05400 & -0.00051 & 29.224 & 29.219 & 0.005 \\
\hline 3 & 3 & 1 & & 3.05274 & 0.00075 & & 29.231 & -0.007 \\
\hline 1 & 1 & 2 & 3.00811 & 3.00805 & 0.00006 & 29.675 & 29.675 & -0.001 \\
\hline 0 & 5 & 0 & 2.96171 & 2.96590 & -0.00419 & 30.150 & 30.107 & 0.044 \\
\hline 2 & 0 & -2 & & 2.96171 & 0.00000 & & 30.150 & 0.000 \\
\hline 0 & 2 & 2 & 2.90857 & 2.90868 & -0.00010 & 30.715 & 30.714 & 0.001 \\
\hline 1 & 5 & 0 & & 2.91097 & -0.00240 & & 30.689 & 0.026 \\
\hline & & $\begin{array}{l}\text { IGU } \\
1 . \\
2 .\end{array}$ & $\begin{array}{l}\text { EES OF ME } \\
\mathrm{M}(24)=4 \\
=(24)=8\end{array}$ & $\begin{array}{l}4 \\
5(0.0037,\end{array}$ & & & & \\
\hline
\end{tabular}




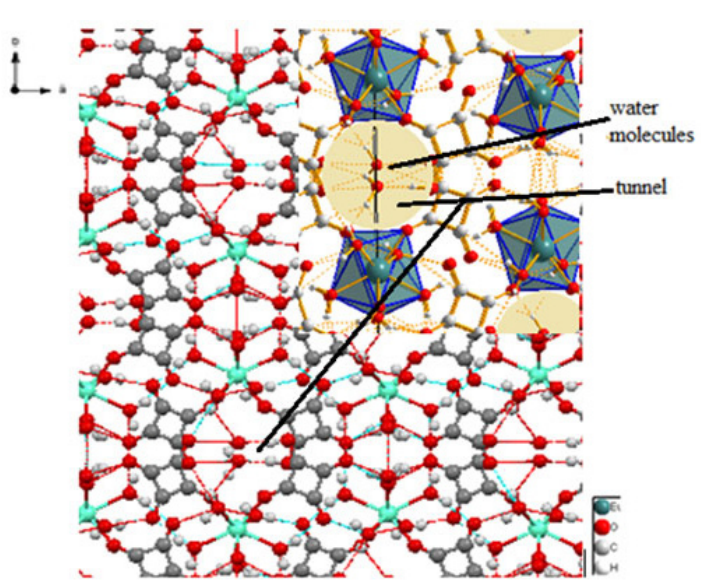

FIG. 2: A packing plot of Eu $\left(\mathrm{H}_{2} \mathrm{O}\right)_{6}\left(\mathrm{C}_{4} \mathrm{O}_{4}\right)$ $\left(\mathrm{HC}_{4} \mathrm{O}_{4}\right) \cdot \mathrm{H}_{2} \mathrm{O}^{15}$ showing the intermolecular hydrogen-bonding scheme and tunnels encapsulates water molecules.

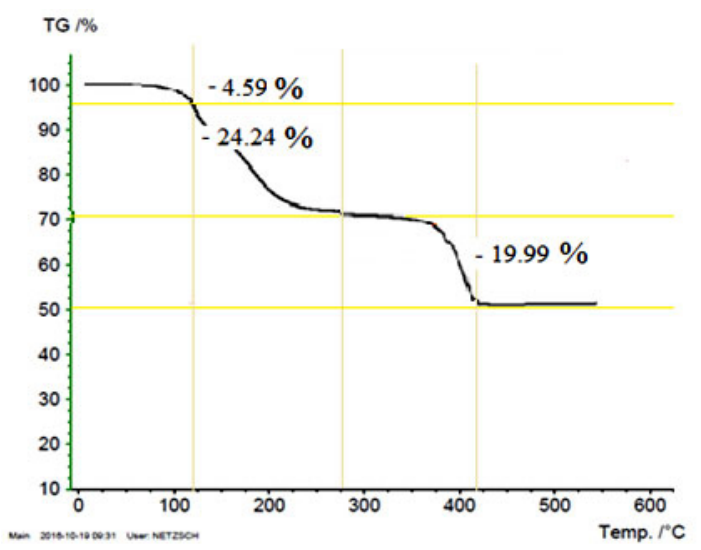

FIG. 3: TG curve of $\mathrm{Y}\left(\mathrm{H}_{2} \mathrm{O}\right)_{6}\left(\mathrm{C}_{4} \mathrm{O}_{4}\right)\left(\mathrm{HC}_{4} \mathrm{O}_{4}\right) \cdot \mathrm{H}_{2} \mathrm{O}$

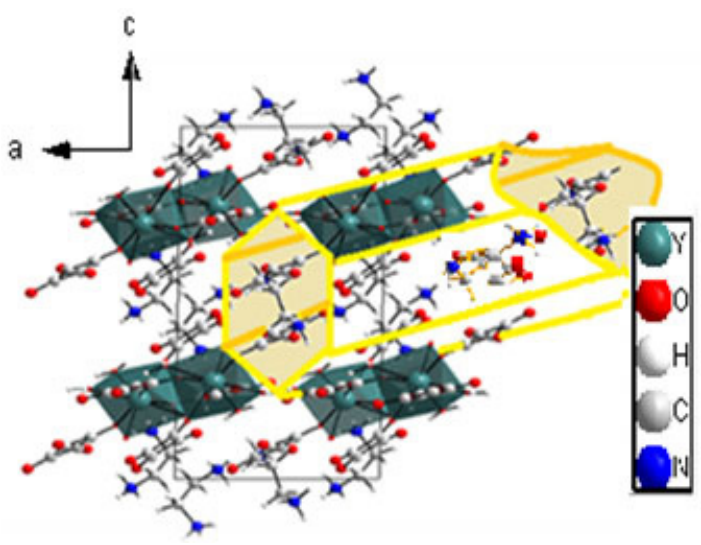

FIG. 4 : Cristal lattice showing porosity of $\left\{\left(\mathrm{C}_{2} \mathrm{H}_{10} \mathrm{~N}_{2}\right) 1.5\left[\mathrm{Y}\left(\mathrm{C}_{4} \mathrm{O}_{4}\right)_{3}\left(\mathrm{H}_{2} \mathrm{O}\right)_{4}\right]\right\} n^{11}$.
$\left\{\left(\mathrm{C}_{2} \mathrm{H}_{10} \mathrm{~N}_{2}\right)_{15}\left[\mathrm{Y}\left(\mathrm{C}_{4} \mathrm{O}_{4}\right)_{3}\left(\mathrm{H}_{2} \mathrm{O}\right)_{4 n}{ }^{11}\right.\right.$. To our knowledge, yttrium, squarate and amine complexes are less common. The structure of these materials with extensive networks including, the amine is specified from the view point of properties of their analogue where the amine is not included in the network.

Catena-poly [sesqui (ethylenedi ammonium)[[tetraaquabis (squarato->O) yttrium (III)]i-squarato->2O: $\mathrm{O}$ '] ] $]^{11}$ complex is characterized by a Two-dimensional crystalline structure. YO8 antiprisms formed constitute linear chains. The amines located between these chains participate, by hydrogen bonding, to interconnect these chains, thus forming layers which develop in parallel and stack along the axis $\mathrm{c}$. They are located approximately $9^{\circ}$ from each other. These layer arrangements reveal channels which develop parallel to the $c$ axis and encapsulate protonated ethylene diamine (FIG 4).

The approach is to make varied the amine, by choosing templates with different carbon chains in their lengths, to favor the modifications of the properties of the material.

In $\mathrm{Y}\left(\mathrm{H}_{2} \mathrm{O}\right)_{6}\left(\mathrm{C}_{4} \mathrm{O}_{4}\right)\left(\mathrm{HC}_{4} \mathrm{O}_{4}\right) \cdot \mathrm{H}_{2} \mathrm{O}$ complex, crystal lattice is characterized by presence of the tunnels along the $c$ axis encapsulating water molecules (zeolite property). FIG2 is reproduced from the crystallographic data file of Complex $\mathrm{Eu}\left(\mathrm{H}_{2} \mathrm{O}\right)_{6}\left(\mathrm{C}_{4} \mathrm{O}_{4}\right)\left(\mathrm{HC}_{4} \mathrm{O}_{4}\right) \cdot \mathrm{H}_{2} \mathrm{O}^{15}$.

\section{CONCLUSION}

In the present work we have demonstrated that based on simple considerations concerning the nature of the metal atoms and coordination behaviour of the ligands the crystal structure of coordination polymers can be controlled to some extent. Whereas the occurrence of two-dimensional grids in these compounds was planned, the formation of the three-dimensional coordination network by interpenetration of these grids was no tin tended. However, compounds were obtained that contain channels in which additional water molecules are embedded.

\section{ACKNOWLEDGMENTS}

We gratefully acknowledge the financial support by the State of MESRS. We are very thankful to Dr. Ammirouch for helpful discussion, and the facility to use his experimental equipment in CRAPC. 


\section{REFERENCE}

1. Chen, B.; Eddaoudi, M.; Hyde, S.T.; O’Keeffe, M.; Yaghi, O.M. Science.2001, 291, 1021.

2. Cavellec, M.R.; Ferey, G.Solid State Sci. 2002, 4, 1221.

3. Murray, L. J.; Dinca, M.; Long, J. R. Hydrogen Chem. Soc. Rev. 2009, 38, 1294"1314.

4. Prasad, P.A.; Neeraj, S.; Natarajan, S., Rao, C.N.R. Chem.Commun. 2000, 1251

5. Dan, M,; Sivashankar, K,; Cheetham, A.K., Rao, C.N.R.J. Sol. Stat. Chem. 2003,174, 60-68

6. Erer, H.; Yesilel, O.Z.; Büyükgüngör, O.Polyhedron 2010, 29, 1163-1167

7. Forster, P.M.; Cheetham, A.K. Angew. Chem. Int. Ed. Engl. 2002, 41, 457.

8. Losier, P.; Zawarotko, M.J, Angew. Chem. Int. Ed. Engl.1996, 35, 2779.

9. Eddaoudi, M,; Kim, J,, Rosi, N,; Vodak, D,;
Wachter, J,; O’Keeffe, M,;Yaghi,O.M, Science 2002, 295, 469.

10. Castro, I,; Calatayud, M.L,; Sletten, J,; Lloret, F,; Julve, M, Inorg. Chim. Acta 1999, 287, 173.

11. Zenkhri, L,; Audebrand, N,; Bataille, T, Acta Cryst. 2011, 67, 529-530.

12. XDR software, program with $X R D$ équipement (Rennes).

13. Boultif, A,; Louer, D,; J. APPL. CRYST. 2004, 37, 724-731.

14. Figure done using the MERCURY 3.8 free ware program from the Cambridge Crystallographic Data Centre.

15. PETIT, J.F,; GLEIZES, A,; TROMBE. Inorg. ChimActa. 1990, 167, 51-68.

16. J. Greve. Journal of Solid State Chemistry, 2003, 175, 328-340 339. 